\title{
The conditional relationship between beta and stock returns: An empirical study in the Colombo Stock Market
}

\author{
M.I.M. Riyath ${ }^{1}$ and Athambawa Jahfer ${ }^{2}$ \\ ${ }^{1}$ Department of Accountancy, Sri Lanka Institute of Advanced \\ Technological Education, Sri Lanka \\ ${ }^{2}$ Department of Accountancy and Finance, \\ Faculty of Management and \\ Commerce, South Eastern University of Sri Lanka, Sri Lanka
}

\begin{abstract}
The objective of this research is to find out the conditional relationship between beta and stock returns for the period 1999 to 2013 in the Sri Lankan market. This study tests whether the beta factor has an ability to influence on the stock returns and attempts to investigate the conditional relationship between beta and stock returns in Sri Lanka. This study reveals that the relationship between beta-return is positive during the up market condition and the relationship is negative during the down market condition in Colombo Stock Exchange during the study period. Therefore, the beta-realized return relationship is hold in the Colombo Stock Exchange with market condition such as up and down markets.
\end{abstract}

Keywords: CAPM; Beta; Stock return; Colombo stock exchange

\section{Introduction}

Since the mid-nineteenth century, pricing of financial securities have been considering important research theme among the corporate finance. From Markowitz (1952) modern portfolio theory, Sharpe (1964), Jensen, Black, \& Scholes (1972), Merton (1976), Fama \& MacBeth (1973) and Black $\&$ Scholes (1974) are developing financial market and asset pricing models for determining stock prices and the factors influencing their variations of stock return. The Capital Asset-Pricing Model (CAPM) is widely used to evaluate portfolio performance and estimate cost of capital of firms (Rossi, 2016). According to the Sharpe (1964), Lintner (1965) and Black (1972) version of CAPM, the beta of a stock is considered as the only factor for variations of return on stocks. (Black, Jensen, \& Scholes, 1972; Fama \& MacBeth, 1973; Stambaugh, 1982).

The CAPM assumes that there is a positive linear relationship exist between the risk of stock measured by beta and its expected (or realized) return. The validity of 
the model is dependent on the following two conditions: first, the market portfolio (often represented by a stock market index) must be efficient, secondly, the existence of a linear relationship between the expected returns and respective beta of stock. These two conditions are inseparable as each necessarily implies the each other. There are numbers of researches have been undertaken in various countries by various researchers but still the results are subjects to debate. The CAPM has been subject to numerous tests especially after Fama \& MacBeth (1973) that have led to contradictory conclusions. (Davis, 1994; Fama \& French, 1992; He \& Ng, 1994; Miles \& Timmermann, 1996; Roll, 1977).

Examining the relationship between stock returns and the factors that influence the stock price has a greater importance to the academics, researchers and investors. There are few factors identified by researchers, which impact on the stock returns in the stock market. Beta is one of the important factor that is mainly influencing the returns of a stock (Black et al., 1972; Fama \& MacBeth, 1973; Stambaugh, 1982). Such Beta factor considered as a variable that has strong empirical evidence in favor of its ability to influence the stock returns, though there are noticeable arguments against this statement with empirical evidences. Indeed, some studies reject the hypothesis that the beta of a stock is the only cause of the systematic factor for the variations in average stock return (Fama \& French, 1992; Lakonishok \& Shapiro, 1984). There are empirical studies of

International Journal of Accounting \& Business Finance the CAPM which emphasize the importance of the conditional specification on the condition of the market by distinguishing the periods of up and down markets. The relationship between the risk of a stock measured by beta, and its average return would not be stable from one condition of market to another.

It seems that in the context of the debate on the empirical verification of the unconditional version of the CAPM, the empirical rejection of the model arises due to the inefficiency of the market index. The CAPM model of Sharpe, Lintner and Black suggests two interrelated conditions: the market portfolio is assumed to be efficient and the expected returns of stocks have a linear relationship with its beta. Many authors do not separate these two conditions insofar as each implies the each other. Indeed, if the market portfolio index appears inefficient, there will be no linear relationship between the expected return of the securities (or portfolios) and its beta.

The validity and fundamental assumption of unconditional CAPM has been tested in Colombo Stock Exchange and the tests provides evidences contradictory to the CAPM (Abeysekera \& Nimal, 2016; Nimal \& Horimoto, 2005; Riyath \& Nimal, 2016; Samarakoon, 1997). Further, many studies examine and find the existence of the conditional relationship between stock returns and beta in various market worldwide. Many empirical tests of conditional CAPM provide that the performance conditional CAPM is better than that of unconditional CAPM (Campbell 
\& Vuolteenaho, 2004; Fletcher \& Kihanda, 2005; Jagannathan \& Wang, 1996; Lettau \& Ludvigson, 2001). However, no recent published evidences regarding the existence of the conditional relationship between stock returns and beta in the Colombo stock exchange as an emerging market in Sri Lanka. Therefore, there is a need for examining the conditional relationship between stock returns and risk in an emerging market like CSE is important. This study tests whether the beta factor has an ability to influence on the stock returns and attempts to investigate the cross sectional relationship between beta and stock returns in Sri Lanka. The finding of this study may provides insights for potential investors to make their investment in a profitable manner and that will positively contribute to our economy.

The rest of paper is organized as follows: Section 2 summaries the literature review. Section 3 describes the data and methodology. Section 4 presents empirical evidence of the study. Section 5 concludes the research.

\section{Literature review}

In the early 1990s, Fama and French, published contradictory results in 1992 and 1993 on the CAPM. In the both articles, they question the relationship between the beta of a security and its average returns between 1963 and 1990, concluding that the CAPM is weak for the period between 1941 and 1990. Fama and French (1992) propose a multifactor model. In addition to the market betas, they taken into account the price-earnings $(\mathrm{P} / \mathrm{E})$ ratio, firm size, book to market ratio and january-effect in explaining the average returns of US exchanges: NYSE, AMEX and NASDAQ. According to Fama and French (1992), if stocks are rationally valued, the risks of equities would be linked to multidimensional factors, such as firm size, book to market ratio.

Other empirical contradictions of the CAPM have been documented by Bhandari (1988), he finds that there is a positive relationship exist between leverage and expected return, which is not explained by Beta. The assumptions of the CAPM should be positive and linear. The studies by Black et al. (1972) and Fama and MacBeth (1973) validated the statements of the model for the period prior to 1969 . However, subsequent studies indicate that the relationship between beta and the expected return on equities might not be significant (Fama \& French, 1992). Pettengill, Sundaram, and Mathur (1995) state that during the up markets (down markets), the relationship between beta and average returns is positive (negative) for the periods from 1936 to 1990. Without distinguishing between up markets and down markets, a positive relationship between beta and average returns is found during the period between 1936 and1950, while it is flat during the periods between 1951-1970 and 1971-1990. Theriou, Aggelidis, Maditinos, \& Šević (2010) test the relationship between beta and return in Athens Stock Exchange (ASE). They finds that there is flat relationship between return and beta when use unconditional CAPM. However, when 
using the conditional CAPM in cross sectional regression analysis, they observe the relationship is significant positive during up market and significant negative during down market condition.

Nimal and Fernando (2013) focus on two markets such as Tokyo Stock Exchange (TSE) is a developed market, and Colombo Stock Exchange (CSE) is an emerging market. The tests reveals that the beta and return relationship is significantly positive during up markets in both TSE and CSE. They suggest that the given market premium, there is systematic relationship between beta and portfolio realized. Nimal (2006a) investigates the conditional relationship between beta and return on individual stocks in the Tokyo Stock Exchange (TSE) and reveals significant conditional relationship is exist between beta and return even when individual stocks returns are considered.

\section{Methodology}

The study includes all common stocks listed in the main board of Colombo Stock Exchange except bank, Finance and insurance sector. The calculation of stocks monthly return includes capital gain, dividend yield with adjustment for share split and right issue of the respective share. Therefore, this study uses the formula adopted by Nimal (2006b) to calculate stock return which is given in the equation. The market data for this study are taken from the data library of CSE. The market return is the returns of all stocks traded in the CSE. Therefore, All Share Price Index (ASPI) is used as proxy to estimate the market return for this study. The monthly return of the three-month Treasury bill rate is considered as proxy for risk free rate which is used to estimate excess return of stocks and the market return.

$$
R_{i t}=\left[\left[\frac{\left[P_{t} P_{c}\left(1+R_{r}+S_{r}+B_{r}+D_{r}\right)\right]}{P_{0}\left(P_{c}+R_{r} P_{r}\right)}\right]-1\right] X 100
$$

Where;

$\mathrm{R}_{\mathrm{it}}$ : Return of the stock i during the period $\mathrm{t}$

$P_{t}$ : Price of the stock at the end of the period $t$

$\mathrm{P}_{0}$ : Price of the stock at the beginning of the period

$D_{t}$ : Dividend payment of the stock during the period $t$

$\mathrm{P}_{\text {od }}$ : Next trading day's opening price of the stock after the dividend

$\mathrm{S}_{\mathrm{r}} \quad$ : Split ratio

$\mathrm{B}_{\mathrm{r}}$ : Bonus ratio

$\mathrm{P}_{\mathrm{c}}$ : Closing price of the stock on Ex-right date / the stock price immediately before the ex-right date

$\mathrm{R}_{\mathrm{r}}$ : Right ratio

$\mathrm{P}_{\mathrm{r}}$ : Right issue price of a stock

$\mathrm{D}_{\mathrm{r}} \quad$ : Dividend ratio

The sample period for this study covers sixteen years from October 1997 to September 2013. The sixteen years are subdivided into six groups each covers six years. The each six-year period again subdivided into three groups each two years as shown in Table 1. The each two years group labeled as portfolio formation period, estimation period and testing period respectively. To include a share in this study, each shares should consist all monthly market share price information for the six years. 
Table-1: Sample Period

\begin{tabular}{|c|c|c|c|}
\hline Group & Portfolio formation period & Estimation period & Test period \\
\hline 1 & $10 / 1997-9 / 1999$ & $10 / 1999-9 / 2001$ & $10 / 2001-9 / 2003$ \\
\hline 2 & $10 / 1999-9 / 2001$ & $10 / 2001-9 / 2003$ & $10 / 2003-9 / 2005$ \\
\hline 3 & $10 / 2001-9 / 2003$ & $10 / 2003-9 / 2005$ & $10 / 2005-9 / 2007$ \\
\hline 4 & $10 / 2003-9 / 2005$ & $10 / 2005-9 / 2007$ & $10 / 2007-9 / 2009$ \\
\hline 5 & $10 / 2005-9 / 2007$ & $10 / 2007-9 / 2009$ & $10 / 2009-9 / 2011$ \\
\hline 6 & $10 / 2007-9 / 2009$ & $10 / 2009-9 / 2011$ & $10 / 2011-9 / 2013$ \\
\hline
\end{tabular}

\section{Portfolio formation period}

During the Portfolio formation period, excess return of each shares listed in the main board of CSE and excess market return are estimated. The beta value estimated for each share by regressing excess stock return on excess market return during the period. Based on the beta value of stocks, all stocks are sorted in descending order and divided into ten equal portfolios. The stocks with highest value are fall under portfolio-1 and lowest value are fall under portfolio- 10 .

$$
\mathrm{R}_{\mathrm{it}}-\mathrm{R}_{\mathrm{ft}}=\alpha_{\mathrm{i}}+\beta_{\mathrm{i}}\left(\mathrm{R}_{\mathrm{mt}}-\mathrm{R}_{\mathrm{ft}}\right)+\varepsilon_{\mathrm{it}}
$$

Where;

$\mathrm{R}_{\mathrm{it}}$ is the return portfolio $i$ at time $\mathrm{t}$,

$\mathrm{R}_{\mathrm{ft}}$ is the risk-free rate of interest at time $\mathrm{t}$,

$\mathrm{R}_{\mathrm{mt}}$ is the return on the market portfolio at time $\mathrm{t}$

$\alpha_{\mathrm{i}}$ is the intercept of portfolio $\mathrm{i}$

$\beta_{\mathrm{i}}$ is coefficient of market factors of portfolio i

$\varepsilon_{\mathrm{et}}$ is the residuals of the portfolio $i$ at time $\mathrm{t}$

\section{Estimation period}

The time series regressions are performed during this two years estimation period to estimate beta for the respective portfolio of stocks. The excess stock returns are regressed on excess market return and estimated stock beta as an output of the regression. The stocks and the respective beta coefficient are assigned to respective portfolio and then portfolio beta is calculated by averaging the beta coefficient of the respective stocks that are assigned to the portfolio. Therefore, number of beta coefficient are equivalent to number of portfolios.

\section{Testing period}

During this two years testing period, excess return of each shares of respective portfolio are calculated. The average excess return of such shares are treated as excess return of respective portfolio. Then portfolio excess return are regressed cross-sectional on portfolio beta that were estimated in estimation period. Therefore, the number of observations are equivalent to number of portfolios.

In order to achieve the objective of the study two different types of cross sectional regression analysis are performed. The first type of regression equation 3.3 is used to test the traditional CAPM while the second type of regression equation 3.4 is used to test the conditional CAPM. 


$$
\begin{gathered}
\mathbf{R}_{\mathrm{ti}}-\mathbf{R}_{\mathrm{ft}}=\gamma_{\mathrm{tt}}+\gamma_{1 \mathrm{t}} \hat{\beta}_{\mathrm{i}}+\text { 团 }_{\mathrm{ti}} \\
\mathbf{R}_{\mathrm{ti}}-\mathbf{R}_{\mathrm{ft}}=\gamma_{0 \mathrm{t}}+\mathbf{D}_{\mathrm{t}} * \gamma_{2 \mathrm{t}} * \hat{\beta}_{\mathrm{i}}+\left(1-\mathrm{D}_{\mathrm{t}}\right) * \gamma_{3 \mathrm{t}} * \hat{\beta}_{\mathrm{i}}+\mathrm{D}_{\mathrm{ti}}
\end{gathered}
$$

Where, $R_{t i}$ is the return of portfolio $i$ at month $t$ that is estimated during the testing period. The $\beta_{\mathrm{i}}$ is the beta of the portfolio $i$ at month $t$ that is estimated in the second step (time series regression). The $\mathrm{D}_{\mathrm{t}}$ is the dummy variable which assumes value equal to 1 when the excess market return is positive and assumes value equal to 0 when the excess market return is negative.

Finally, the following hypothesis are formulated to test unconditional and unconditional CAPM using estimated average value of cross sectional regression coefficients of the Fama and MacBeth (1973) adjusted t-statistic equation-3.5.

The unconditional CAPM is a valid model in explaining cross sectional variation of stock return in CSE.

$$
\begin{aligned}
& H_{0}: \overline{\gamma_{1}} \leq 0 \\
& H_{1}: \overline{\gamma_{1}}>0
\end{aligned}
$$

The conditional CAPM is a valid model during excess market return is positive (Up Market) in explaining cross sectional variation of stock return in CSE.

$$
\begin{aligned}
& \mathrm{H}_{0}: \overline{\gamma_{2}} \leq 0 \\
& \mathrm{H}_{1}: \overline{\gamma_{2}}>0
\end{aligned}
$$

The conditional CAPM is a valid model during excess market return is negative (Down Market) in explaining cross sectional variation of stock return in CSE.

$$
\begin{aligned}
& H_{0}: \overline{\gamma_{3}} \geq 0 \\
& H_{1}: \overline{\gamma_{3}}<0
\end{aligned}
$$

The use of the individual value of cross sectional regression coefficient estimates and associated t-tests are not enough to make statistical inference. Therefore, Fama and MacBeth (1973) introduced a statistical test called as Fama and MacBeth (1973) adjusted t-statistic to make appropriate statistical inference. The statistical inference is done for this study using the Fama and MacBeth (1973) adjusted t-statistic equation-3.5.

$$
t\left(\overline{\gamma_{k}}\right)=\frac{\overline{\gamma_{k}}}{\frac{s d\left(\overline{\gamma_{k}}\right)}{\sqrt{T}}}
$$

Where;

$\gamma_{k}$ is the average of $k^{\text {th }}$ coefficient estimate of cross sectional regression $\operatorname{sd}\left(\gamma_{k}\right)$ is the standard deviation of the $\gamma_{k}$ $\mathrm{T}$ is the number of time series observations.

\section{Findings and results}

The table 2 shows the market characteristics for the period of 144 months from October 2001 to September 2013. It shows that the excess market return in the full sample period is $1.3002 \%$ that is positive and insignificant. It suggest that the market premium is not statistically different from zero. However, during the up market condition the market portfolio earns positive market premium of $6.923 \%$ while during the down market condition it earns negative market premium of -4.984 . These market premiums are during the conditional period statistically different from zero. It provides evidences for existence of conditional effect in the Colombo Stock Exchange during the study period. Further, the number of months of down market condition is higher 
(Negative market premium) than the up market condition during the full sample period. It suggest that the earlier studies done regarding the test of unconditional/ traditional CAPM in this market without considering the market condition may provide biased finding. Therefore, these evidences provide necessity for testing conditional CAPM in the CSE.

Table 2: Market Characteristics

\begin{tabular}{|c|c|c|c|c|}
\hline & & Unconditional & Up Market & Down Market \\
\hline \multirow{4}{*}{$\begin{array}{c}\text { Full Sample } \\
10 / 2001-09 / 2013\end{array}$} & Number of months & 144 & 68 & 76 \\
\hline & Excess market return & 1.3002 & 6.923 & -4.984 \\
\hline & T statistics & 1.896 & 10.309 & -9.835 \\
\hline & p-value & 0.059 & 0.000 & 0.00 \\
\hline \multirow{4}{*}{$\begin{array}{c}\text { Sub period } \\
\text { 10/2001-05/2009 } \\
\text { Civil War }\end{array}$} & Number of months & 92 & 50 & 42 \\
\hline & Excess market return & 1.2550 & 6.9882 & -5.5701 \\
\hline & T statistics & 1.4489 & 8.1943 & -7.70529 \\
\hline & p-value & 0.1508 & 0.000 & 0.000 \\
\hline \multirow{4}{*}{$\begin{array}{c}\text { Sub period } \\
\text { 06/2009-09/2013 } \\
\text { Post-Civil War }\end{array}$} & Number of months & 52 & 26 & 26 \\
\hline & Excess market return & 1.3801 & 6.7965 & -4.0363 \\
\hline & T statistics & 1.4086 & 6.1724 & -6.7540 \\
\hline & p-value & 0.1650 & 0.000 & 0.000 \\
\hline
\end{tabular}

Further, the sample period is divided into two different sup sample period based on civil war. Economic and finance system were effected due to civil war in Sri Lanka. The first sub sample period represent the later part of the civil war from October 2001 up to the end on May 2009. The second sub sample covers the post-civil war period from June 2009 to September 2013. The excess market return is positive and insignificant during the both sub sample periods under unconditional. At the same time, the excess market return of the up market is significantly positive during both sub sample period and whole study period while in the down market and conditional period and negative respectively during the study period.

Table 3 shows the test result of the cross section regression equation 3.3. The results provides beta coefficient with $\mathrm{t}$-value and p-value. The beta coefficient in the unconditional CAPM provides negative value during the all the sample period. However, the beta coefficient is significant during the full sample period and second sub sample (post-civil war) period while the beta coefficient is insignificant during the first subsample (civil war) period. It suggests that the relationship between beta and expected return is negative. The traditional unconditional CAPM states that the 
relationship between beta and expected return is positive and linear. This finding is inconsistent with fundamental assumption of CAPM and invalidated the unconditional CAPM in the CSE.

Table 3

\begin{tabular}{cccc}
\hline Sample Period & Beta & T-statistics & P value \\
\hline $2001 / 10-2013 / 09$ & -0.9668 & -182.41 & 0.000 \\
$2001 / 10-2009 / 05$ & -0.0151 & -1.69363 & 0.092 \\
$2009 / 06-2013 / 09$ & -2.6504 & -91.6467 & 0.000
\end{tabular}

Table 4 presents the test result of the cross section regression equation 3.4 for the conditional CAPM during the full sample and the sub sample periods in the up and down conditional markets. The beta coefficient are becomes positive and significant when the market is segmented into up market during the full sample period and first subsample period of 10/2001 - 05/2009. Meanwhile, beta coefficient are becomes negative and significant when the market is segmented into down market during the full sample period and both subsample periods. However, the beta coefficient is still negative and significant even though the market is segmented into up market condition during the sub sample period 06/2009 - 09/2013. The possible reason for the negative beta coefficient during the period 06/2009 $09 / 2013$ may be there are substantial rapid changes are happened in CSE, after end of thirty years civil war in Sri Lanka (Colombo Stock Exchange, 2014; Dayaratne, 2014;
Securities \& Exchange Commission of Sri Lanka, 2014). Further, inflation and interest rate of Sri Lanka was very high during the period from early 2007 to mid of 2009 . The high inflation was increased due to the peaked government expenditure on civil war and government has printed money to meet the war expenditure during the latter part of the civil war (Pallegedara, 2012). The Sri Lanka Inter Bank Offer Rate (SLIBOR) was recorded as $24.83 \%$ in March 2007. The behavior of ASPI during the sample period is shown in figure-1. The ASPI has shown an abnormal increases immediate after the end of civil war up to early in 2011. The ASPI index was 1821 as at January 2009 and reached at the top as 7798 as at February 2011. This abnormal increases in ASPI has started to decrease and reached low level of 4832 as at May 2012. These abnormal changes has impact on stock market operations significantly, which may affect the relationship and significance of market factor in the CSE. 
Table 4

\begin{tabular}{|c|c|c|c|c|}
\hline Sample Period & Condition & Beta & T-statistics & P value \\
\hline \multirow{2}{*}{$10 / 2001-09 / 2013$} & Up market & 0.2340 & 13.74152 & 0.000 \\
& Down Market & -2.4297 & -229.237 & 0.000 \\
\hline $10 / 2001-05 / 2009$ & Up market & 1.7856 & 68.7190 & 0.000 \\
& Down Market & -2.1589 & -111.954 & 0.000 \\
\hdashline $06 / 2009-09 / 2013$ & Up market & -2.74983 & -26.0158 & 0.000 \\
& Down Market & -2.55107 & -54.2803 & 0.000 \\
\hline
\end{tabular}

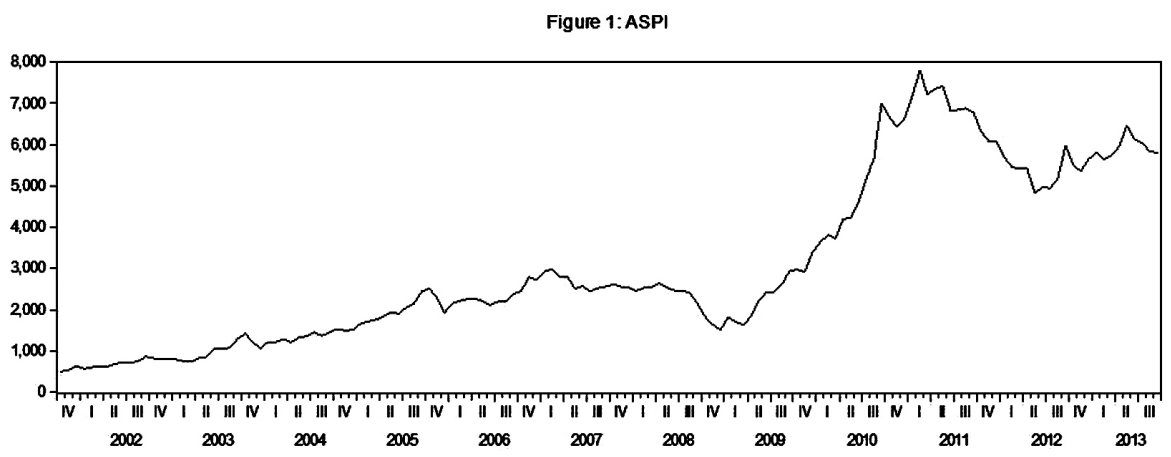

\section{Conclusion}

The traditional unconditional CAPM of Sharpe (1964), Lintner (1965) and Black (1972) states that the beta-realized return relationship is positive and liner. Many studies after Fama and Macbeth (1972) provides evidences against the unconditional CAPM. The negative market premium is recorded in many periods during the study period in CSE. It provides a necessity for test of conditional CAPM in the market. Further, the previous studies conducted in the market without considering the conditional relationship may provide biased finding on the beta-realized return relationship. This study reveals that the relationship between beta- return is positive during the up market condition and the relationship is negative during the down market condition in CSE during the study period. Therefore, the betarealized return relationship is hold in the CSE with market condition such as up and down markets. The finding is consistent with the findings of Nimal and Fernando (2013), Pettengill et al. (1995), Hodoshima, Garza-Gómez, and Kunimura (2000) and Theriou et al. (2010).

\section{Refernces}

Abeysekera, A. P., \& Nimal, P. D. (2016). The Four Factor Model and Stock Returns: Evidence From Sri Lanka. Afro-Asian Journal of Finance and Accounting, 7(1), 1-15.

Ball, R. (1978). Anomalies in relationships between securities' yields and yield- 
surrogates. Journal of Financial Economics, 6(2-3), 103-126.

Banz, R. W. (1981). The relationship between return and market value of common stocks. Journal of Financial Economics, 9(1), 3-18.

Basu, S. (1983). The relationship between earnings' yield, market value and return for NYSE common stocks: Further evidence. Journal of Financial Economics, 12(1), 129-156.

Bhandari, L. C. (1988). Debt/Equity Ratio and Expected Common Stock Returns: Empirical Evidence. Journal of Finance, 43(2), 507-528. doi: DOI: $10.2307 / 2328473$

Black, F. (1972). Capital market equilibrium with restricted borrowing. Journal of business, 444-455.

Black, F., Jensen, M. C., \& Scholes, M. S. (1972). The capital asset pricing model: Some empirical tests. Studies in the theory of capital markets, 79124.

Black, F., \& Scholes, M. (1974). The effects of dividend yield and dividend policy on common stock prices and returns. Journal of Financial Economics, 1(1), $1-22$.

Campbell, J. Y., \& Vuolteenaho, T. (2004). Bad beta, good beta. The American Economic Review, 94(5), 1249-1275.

Colombo Stock Exchange. (2014). Invest in Sri Lanka: Be a Part of South Asia's Strongest Growth Story: Colombo Stock Exchange,

Davis, J. L. (1994). The Cross-Section of Realized Stock Returns: The Pre- compustat evidence. The Journal of Finance The Journal of Finance, 49(5), 1579-1593.

Dayaratne, D. (2014). A Comparative study for pre and post war performance of Colombo Stock Exchange (CSE). Sabaragamuwa University Journal, 13(1).

Fama, E. F., \& French, K. R. (1992). The cross section of expected stock returns. The Journal of Finance, 47(2), 427-465.

Fama, E. F., \& MacBeth, J. D. (1973). Risk, return, and equilibrium: Empirical tests. The Journal of Political Economy, 607-636.

Fletcher, J., \& Kihanda, J. (2005). An examination of alternative CAPMbased models in UK stock returns. Journal of Banking \& Finance, 29(12), 2995-3014.

He, J., \& Ng, L. K. (1994). Economic forces, fundamental variables, and equity returns. Journal of business, 599-609.

Hodoshima, J., Garza-Gómez, X., \& Kunimura, M. (2000). Crosssectional regression analysis of return and beta in Japan. Journal of Economics and Business, 52(6), 515533.

Jagannathan, R., \& Wang, Z. (1996). The conditional CAPM and the crosssection of expected returns. Journal of Finance, 3-53.

Jensen, M. C., Black, F., \& Scholes, M. S. (1972). The capital asset pricing model: Some empirical tests.

Lakonishok, J., \& Shapiro, A. C. (1984). 
Stock Returns, Beta, Variance and Size: An Empirical Analysis. Financial Analysts Journal Financial Analysts Journal, 40(4), 36-41.

Lettau, M., \& Ludvigson, S. (2001). Resurrecting the (C) CAPM: A cross sectional test when risk premia are time varying. Journal of Political Economy, 109(6), 1238-1287.

Lintner, J. (1965). The valuation of risk assets and the selection of risky investments in stock portfolios and capital budgets. The review of economics and statistics, 47(1), 13-37.

Merton, R. C. (1976). Option pricing when underlying stock returns are discontinuous. Journal of Financial Economics, 3(1-2), 125-144.

Miles, D., \& Timmermann, A. (1996). Variation in expected stock returns: evidence on the pricing of equities from a cross-section of UK companies. Economica, 369-382.

Nimal, P. D. (2006a). The Conditional Relation between Beta and Returns: Evidence from Japan (酒井泰弘教授 退職記念論文集). The Hikone Ronso, 357, 195-214.

Nimal, P. D. (2006b). Empirical Analysis of the Capital Asset Pricing Model. (Ph.D), University of Shiga, Japan.

Nimal, P. D., \& Fernando, S. (2013). The Conditional Relation between Beta and Returns: Evidence from Japan and Sri Lanka. The Hikone Ronso, 395, 94-105.

Nimal, P. D., \& Horimoto, S. (2005). Size, BE/ME, Beta, E/P and Stock Returns:
Evidence from TSE 1st Section:

Working paper.

Pallegedara, A. (2012). Dynamic

Relationships between Stock Market

Performance and Short Term Interest

Rate-Empirical Evidence from Sri Lanka.

Pettengill, G. N., Sundaram, S., \& Mathur, I.

(1995). The conditional relation between beta and returns. Journal of Financial and Quantitative Analysis, 30(1), 101-116.

Reinganum, M. R. (1982). A direct test of Roll's conjecture on the firm size effect. The Journal of Finance, 37(1), 27-35.

Riyath, M. I. M., \& Nimal, P. D. (2016). Comparative Study on Asset Pricing Models in Explaining Cross Sectional Variation of Stock Returns in the Colombo Stock Exchange. Paper presented at the 13 th International Conference on Business Management, University of Sri Jayeward eneprua.

Roll, R. (1977). A critique of the asset pricing theory's tests Part I: On past and potential testability of the theory. Journal of Financial Economics, 4(2), 129-176.

Rossi, M. (2016). The capital asset pricing model: a critical literature review. Global Business and Economics Review, 18(5), 604-617.

Samarakoon, L. P. (1997). The cross-section of expected stock returns in Sri Lanka. Sri Lankan Journal of Management, 2(3), 234-250. 
Securities \& Exchange Commission of Sri Lanka. (2014). Capital Market Progress Report: Colombo Stock Exchange, Sri Lanka.

Sharpe, W. F. (1964). Capital asset prices: A theory of market equilibrium under conditions of risk. The Journal of Finance, 19(3), 425-442.

Stambaugh, R. F. (1982). On the exclusion of assets from tests of the two-parameter model: A sensitivity analysis. Journal of Financial Economics, 10(3), 237268.

Theriou, N. G., Aggelidis, V. P., Maditinos, D. I., \& Šević, Ž. (2010). Testing the relation between beta and returns in the Athens stock exchange. Managerial Finance, 36(12), 10431056. 